\title{
Semiotic approaches to advertising texts and strategies: Narrative, passion, marketing
}

CINZIA BIANCHI

Abstract

This paper provides an overview of semiotic studies about advertising, beginning with the early work done in the 1960s. Advertising communication plays a particular role in semiotic studies in the second half of the twentieth century. Pioneering studies of advertising messages, in particular those of Roland Barthes and Umberto Eco, date to the 1960s and were carried out for the most part using the tools of classical rhetoric. Following a period in which semiotics displayed a relative lack of interest in advertisements, in the 1980s advertising texts were used as examples in applied narratological analysis by JeanMarie Floch and others. This occurred at the same time as the so-called "passion turn of semiotics," which stressed that the passions and emotions present in texts are crucial issues in textual semiotics, and it also seemed to offer fresh perspectives for the analysis of advertising communication. The passion turn took account of the evolution of advertising itself, since modern advertising is more and more interested in conveying passions and emotions. The effectiveness of an advert tends to be closely bound up with the presentation of sensations associated with a given product or brand. Recently, semioticians have begun to study more general features of advertising and marketing discourse.

Keywords: advertising; semiotics; passion; marketing; narrative; spot.

\section{Introduction}

Advertising communication plays a rather particular role in semiotic studies in the second half of the twentieth century. Pioneering studies of advertising messages, in particular those of Roland Barthes and Umberto Eco, date to the 1960s, and were carried out for the most part using the tools of classical 
rhetoric. Following a period in which semiotics displayed a relative lack of interest in advertisements, in the 1980s advertising texts were used as examples in applied narratological analysis by Jean-Marie Floch and others. This occurred at the same time as the so-called "passion turn of semiotics," which stressed that the passions and emotions present in texts are crucial issues in textual semiotics, and it also seemed to offer fresh perspectives for the analysis of advertising communication. The passion turn took account of the evolution of advertising itself: it should in fact be evident that modern advertising is less and less interested in telling stories and more and more in conveying passions and emotions. The effectiveness of an advert tends to be closely bound up with the presentation of sensations associated with a given product or brand. Recently, semioticians have begun to study more general features of advertising and marketing discourse.

The aim of this paper is to provide an overview of semiotic studies about advertising, beginning with the early work done in the 1960 s.

\section{Semiology as rhetorical analysis of advertising}

The first semiological studies of advertising started from the presupposition that it is a communicative activity with a persuasive purpose, given that it seeks to induce people to buy a given product. It is only natural, then, to turn to studies in the humanistic and literary tradition that have tried to explain the art of persuasion, as classical rhetoric did. Although, as Marrone (2001: 138143) notes, semiological studies of advertising have a descriptive rather than an evaluative intent, they are nonetheless quite critical of advertising communication because it basically seems to render rhetorical techniques banal. The fact that noble arts are used for persuasive or, as Eco (1968) was to put it, "consolatory" goals considerably downscales the creative side of any rhetorical inventio. ${ }^{1}$ The use of rhetorical figures and tropes seems to be essentially dictated by purely formal rather than genuinely linguistic concerns; advertising language is completely dependent on everyday language, from which it takes idiomatic expressions and syntactic rules, and what inevitably predominates is its nature as a persuasive discourse with specific economic goals (see Marrone 2001: 138-141).

The focus of these studies, which can be credited with having given due consideration to a form of communication whose cultural and social significance would only subsequently be understood, was on the linguistic aspects of the advertising message. Semiological interest in the advertising image first emerged in the work of Roland Barthes. 


\subsection{Barthes: The search for a grammar of the image}

In 1964, two essays by Roland Barthes, "Eléments de sémiologie" and "Rhétorique de l'image," were published in the journal Communications. They attracted considerable interest in cultural circles at the time, and contained some of the key concepts of Barthesian semiology, including the concepts of the code, the sign, and the distinction between connotation and denotation. ${ }^{2}$ These were then applied in the analysis of an advert for a well-known brand of French pasta. In theoretical terms, Barthes's work was based on a rereading of Saussure and motivated by the attempt to transpose the Saussurian linguistic model onto other systems of signification and use it for new subjects of analysis. In Mythologies, which had appeared a few years earlier in 1957, Barthes had turned his attention to the products of mass communication, strip cartoons, the cinema and advertising. Adopting a procedure that involved "breaking down" the object in order to understand how it functioned, semiology seemed to have something original and quite specific to say about these phenomena. The two essays prompted widespread debate and study in the years that followed. It is worth, then, examining more closely Barthes's analysis of the advertisement for Panzani pasta.

The theoretical issue that Barthes was anxious to tackle concerned the meaning of the image. Is it possible, he asks at the beginning of his essay, for analogical representation, which is what an image is, to produce real systems of signs as conceived of by linguistics? Or does it remain ineffable and mysterious to the extent that it must be regarded as relatively unstructured and semantically rudimentary? In order to answer this question, Barthes analyzed an advertising image, because "in advertising the signification of the image is undoubtedly intentional; the signifieds of the advertising message are formed a priori by certain attributes of the product and these signifieds have to be transmitted as clearly as possible." The advertising image is a good subject for analysis because it is "frank" and emphatic. In fact, if signs can be identified in it, one can be sure that "these signs are full, formed with a view to the optimum reading" (Barthes 1977: 33). ${ }^{3}$

The image in question (see Figure 1) can be described as follows: there is a half-open string bag containing tomatoes, peppers, a mushroom, a can, a sachet, and some packets of spaghetti. One or two of the items are spilling out of it.

According to Barthes, it is possible to identify a preliminary linguistic message: the product labels and the caption, which reads "Pâtes - Sauce Parmesan à l'italienne de luxe" and employs a specific code, i.e., the French language. To this one must add a further signified relating to the name of the brand, "Panzani," which refers in a connotative fashion to /Italianicity/. Putting the linguistic aspect to one side and focusing on the pure image, it can be said that it seems above all else to indicate "a return from the market," with 


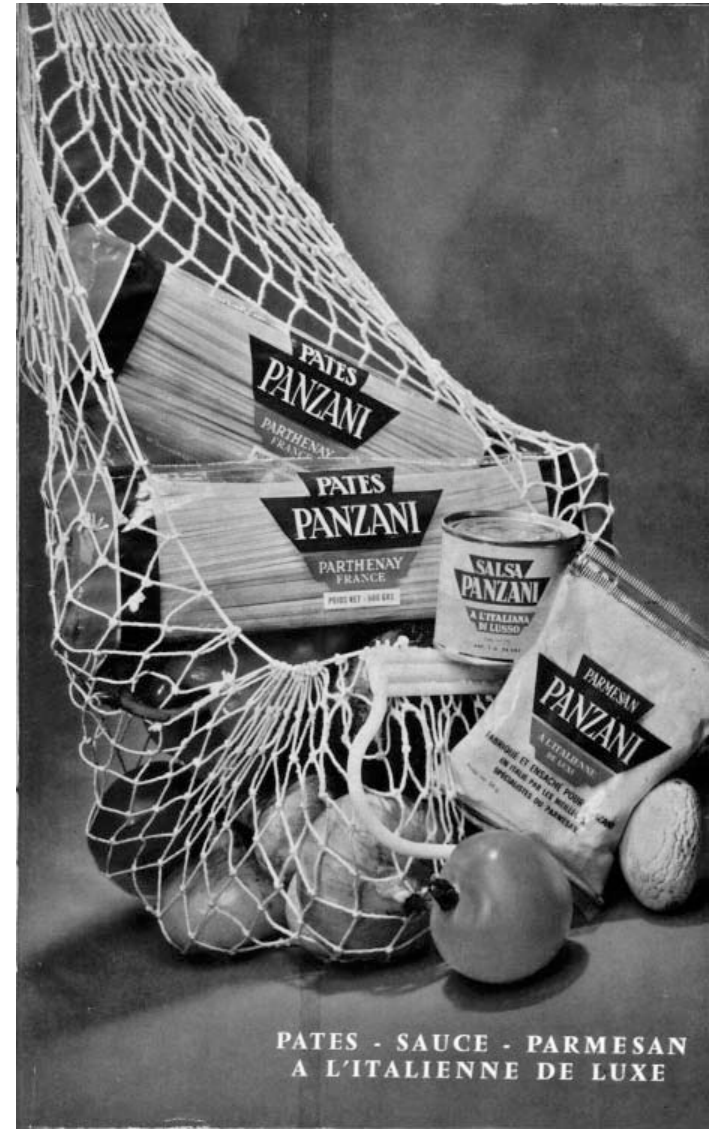

Figure 1. Panzani pasta advertisement

emphasis being placed on "the freshness of the products" and "the essentially domestic preparation for which they are destined" (Barthes 1977: 34). There is, then, a sign - "shopping bag" — in which the signifier is the image of the bag and the signified is the concept of /bag/. As a whole, this in turn becomes the signifier of a connotation whose signified is the concept of /home cooking/. There is also a second sign, where the signifier is the tomato, the pepper, and the tri-colored hues, and the signified, also connotative, is /Italianicity/. This is redundant with regard to the connotated sign of the linguistic message. Nestled in the image are a number of further signs the deciphering of which requires cultural knowledge; for instance, the arrangement of the ingredients points to an aesthetic signified in that it evokes a whole series of pictorial still lifes. 
The image is therefore much more complex than the linguistic message. The written words do, however, have the fundamental function of anchoring the reading of the image, in itself polysemous, to the objects, indicating a level of perception and guiding interpretation. This anchorage, Barthes goes on to say (1977: 38-40), has a controlling or even a repressive function with regard to the liberty of the signifieds of the image, and it is for this reason that "the morality and ideology of a society are above all invested" at a textual level.

However, the image to which the linguistic message is anchored has, as it were, two souls, which take the form of two relationally defined messages, one literal and denotative, and the other "symbolic" and connotative. The former acquires meaning at the level of the identification of the represented scene: the image stands there insofar as it is a representation of something else. But the image denoted "in a pure state" has a crucial function: given that it does not imply any code, "it naturalizes the symbolic message, it innocents the semantic artifice of connotation, which is extremely dense, especially in advertising" (1977: 45). It remains in the photograph as a kind of "natural being there of objects," which seem to be reproduced quite spontaneously in the represented scene. The signs of culture are erased, making way for what appears to derive directly from nature.

The third message in the Panzani advert is therefore connotative and is the real symbolic message. Its signs are drawn from a cultural code, identifiable in that they are forms of knowledge - practical, national, cultural, aesthetic invested in the image. They have their own ideology (unique to a given society and history, even though it may resort to various different signifiers of connotation), the "signifying aspect" of which is rhetoric. Bound up as it is with ideology and culture, the rhetoric of the image has nothing fake and artificial about it at all. There is no implied subordination of any kind to the rhetoric of the written text; rather it identifies specific rhetorical forms of the image, which seem, for example, to favor certain figures rather than others. Barthes himself emphasizes that the most common rhetorical figures in advertising are metonymy and asyndeton, that is the juxtaposition of images without the usual conjunctions between them.

\subsection{Eco and the "consolatory" art}

The analysis of advertising carried out by Umberto Eco in La struttura assente, published four years later in 1968, continued along the same lines as Barthes's work. Advertising was once again viewed as suitable terrain for examining visual codes in terms of the relations between rhetoric and ideology. Eco (1968: 165-167) basically set out to provide a response to the following questions: if the technique of advertising deliberately alters the referential function of the 
terms in an advert by confounding "a system of rhetorical expectations" (thereby attracting the viewer's attention), does such a violation lead to a "nutritious" growth at the level of ideological persuasion? And to what extent, insofar as it is apparently novel but actually a reiteration, is it merely "consolatory" rather than nutritious?

In order to answer these questions, Eco analyzes a number of adverts, noting above all that advertising codes function according to a dual register, verbal and visual. However, their relationship is more complex than the one envisaged by Barthes; according to Eco, it cannot be assumed that the anchorage is always provided by the verbal element. Sometimes this function is performed by the visual component with the aid of various rhetorical devices. He illustrates this idea by analyzing a well-known advertisement for Camay soap. The visual register is as follows:

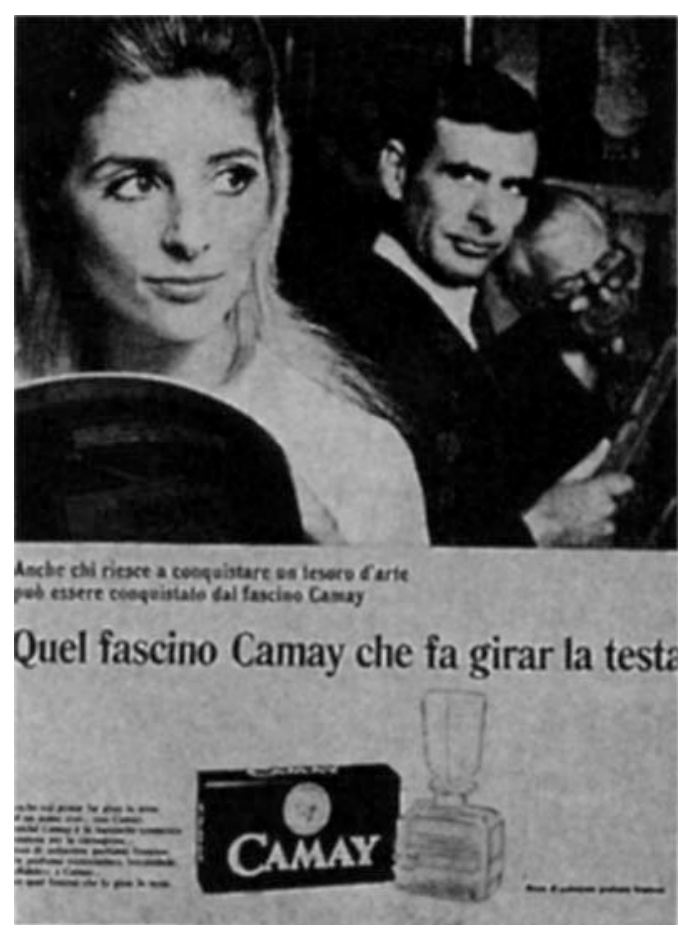

Figure 2. Advertisement for Camay soap

A man and a woman are examining some paintings on display at Sotheby's of London, a place visited by well-off people with an interest in antiques. The man is looking at the woman, and the woman's eyes are turned towards that gaze. The seme /woman/ comprises a series of connotations: the woman is 
beautiful (according to currently accepted codes), she is presumably northern European (connotation of prestige), rich, refined, and with good taste (otherwise she would not be at Sotheby's), and, if not English, then almost certainly a very classy tourist. The man is virile and confident (as shown by the iconographic codes); he is probably more refined and expert than the woman because he does not need to consult a catalogue to find his way around what is up for sale at the auction house. Instead, he is looking directly at the paintings together with another older gentleman. If taken as an isolated shot in a sequence, the image tells us that the woman senses she is being observed and is trying to see who is looking at her without, however, betraying her interest. The man, on the other hand, is clearly distracted by the woman's presence, because he breaks off what he is doing with the older man, who continues to look at the picture. As the anchoring linguistic message establishes that the cause of the fascination is the fragrance of Camay soap, the iconic seme at the bottom introduces a redundant function by means of a double metonym: "bar of soap + bottle of perfume" means /bar of soap = bottle of perfume/.

Looking now at the linguistic register, the key idea in the pay-off ( Quel fascino Camay che fa girare la testa, which can roughly be translated as "The head-turning fascination of Camay") and in the headline (Anche chi riesce a conquistare un tesoro d'arte puo essere conquistato dal fascino Camay, that is "Even someone who manages to conquer an art work can be conquered by the fascination of Camay") is developed in the text of the message:

Anche voi potete far girar la testa ad un uomo così . . con Camay. Perché Camay è la saponetta cosmetica preziosa per la carnagione ... ricca di seducente profumo francese. Un profumo costosissimo, irresistibile. Affidatevi a Camay ... per quel fascino che fa girar la testa.

"You too can turn the head of a man like that ... with Camay. Because Camay is a cosmetic soap bar that is precious for the complexion ... rich in seductive French perfume. A fabulously expensive and irresistible perfume. Turn to Camay . . . for the fascination that turns heads" (my translation).

It is worth noting that expressions like prezioso, seducente, costosissimo, irresistibile, and girar la testa have fairly elementary associations that as a whole seem to contrast, Eco argues, with the visual register. The latter has highbrow connotations (culture, internationality, love of art, wealth, taste) that the linguistic register does not encourage. The text does not talk, for instance, about taste or a love for art, but about "conquering an art treasure," stressing the economic connotations. It is as if the visual message is directed towards a more limited audience, while the linguistic one selects "a wider audience responsive to less sophisticated impulses." It might even be that the refined addressee is attracted by the sophisticated visual message but repulsed by the 
crudeness of the linguistic one. There seems, then, to be "a curious contradiction on the part of the addresser, who is inspired by more sophisticated advertising models for the visual dimension but relies for the linguistic part on tried and tested systems of persuasion used on radio or in graphically straightforward advertisements" (Eco 1968: 176, my translation).

The rhetorical analysis of this and other advertisements leads Eco to a number of general conclusions about advertising. He argues that all it does is to repeat what the user expects, and the ideology it evokes is always that of consumption, posited in uncritical terms. As advertising communication has to resort to what has already been acquired by the collectivity, it always makes use of codified solutions and as a consequence can never be anything other than "consolatory." It is therefore up to the semiologist to unmask the illusions generated by the media system: "In this respect a rhetorical map of advertising would help to define without any possible misunderstanding the extent to which the advertiser, who is under the illusion that he is inventing new expressive formulas, is effectively spoken by his own language" (Eco 1968: 188, my translation).

\section{From the message to the advertising text}

The studies by Barthes and Eco are just two analyses of advertising messages, perhaps the most famous ones, although at the beginning of the 1970s many other studies did devote considerable attention to this particular form of discourse, exploring a range of issues, including the semantics, rhetoric, style, ideological presuppositions, and the mythological nature of advertising. However, the interest of semioticians in advertising faded quite rapidly, as they found it more fruitful to explore other theoretical areas. As Semprini (1990: 16-17) emphasizes, there are two possible explanations for this shift in attention. One is sociocultural: as advertising encouraged consumerism and invoked traditional values and behavioral stereotypes, it became the favorite target of critics of consumer society in the 1970s. Once semiology had lost the prerogative of social criticism and its vocation for unmasking ideology, advertising seemed a less promising field for analysis than others. The other possible explanation for the loss in interest, according to Semprini, is theoretical, because semiological analysis, especially of the kind done by Barthes, seemed rightly or wrongly to end up being a mere classification of the rhetorical figures present in individual advertisements.

Although semiologists abandoned rhetorical analysis and only began analyzing it closely again in the middle of the 1980s (with a different set of tools), advertising is undoubtedly the field in which early semiological studies, especially those of Barthes and Eco, had a broad reception, to the extent that they 
are often the only acknowledged contribution of the semiotic discipline to advertising analysis and creativity. ${ }^{5}$ In actual fact the theoretical limits of the semiological approach were mainly superseded by Greimas, who "set out to describe the mechanisms for generating meaning, first of all in verbal language and then, thanks also to the development of the notion of the text in linguistics, in all languages, including figurative and plastic ones" (Semprini 1990: 17, my translation). Attending to the mechanisms of signification - rather than those of communication - Greimas tried to explain how meaning is organized, describing its narrative logic by way of his "generative trajectory of meaning." This tool was particularly important for the analysis of audiovisual advertisements (see section 4.1). But before describing this aspect of advertising communication in more detail, it is worth focusing on another essay by Greimas on visual semiotics, which has also proved fundamental for advertising analysis.

\subsection{The foundations of figurative semiotics and the semiotics of the plastic arts}

Published in 1984, Greimas's Sémiotique figurative et sémiotique plastique established the structural foundations for a visual semiotics. In it, he investigates what he called planar representations, which include pictorial, graphic, and photographic texts. According to Greimas, every visual text essentially operates on two levels, the figurative and the plastic. The figurative level enables the recognition of objects and individuals belonging to the natural world through the identification of the figurative formants. At the plastic level, on the other hand, the signifier is divided up differently, no longer in terms of the recognizability or otherwise of figures in the natural world, but of the visual features, articulated in plastic formants, which prompt another kind of reading of the text based on three categories: topological (the spatial organization of the painting), eidetic (the form of the objects) and chromatic (the colors).

Starting with the analysis of these three basic categories, Greimas argues, it is possible to distinguish three types of visual text: abstract visual texts, for which the only possible form of analysis is plastic (as, for instance, with the so-called abstract paintings of contemporary art); figurative texts, in which figurative formants can be identified (insofar as they are clearly identifiable figures of the world); and iconic texts, which are densely figurative and display a greater resemblance to the real (understood from an anti-referential perspective as an "effect of meaning").

Identification of the figurative and plastic formants is therefore the core process in any comprehension of a visual text. Not all of the innumerable graphic features or areas surrounded by lines or shades of color are formants of a given 
text; only those to which value is liable to be attributed at the level of content are called formants. ${ }^{6}$ But while figurative formants only begin to signify when the reading grid of the natural world is applied, plastic formants acquire significance in relation to the plane of content, a relationship that can be of two types: symbolic or semi-symbolic. In the first case there is a match between isolated elements on the plane of expression and on the plane of content, whereby a plastic formant refers to a cultural unit symbolically, by convention. In so-called symbolic semiotics, there is therefore a "one-to-one" correspondence between the expressive feature and the content feature. In semi-symbolic semiotics, on the other hand, there is a correspondence between the categories of the plane of expression and categories of the plane of content when the visual traits are organized into plastic contrasts, in other words if opposite, contrasting or contradictory terms of the same plastic category are co-present on the same surface. In this case, an opposition on the plane of expression has the task of conveying an opposition on the plane of content, and is homologous to it. It is as if another plastic language were formed in visual texts, in which the content is closely tied to the organization of the plane of expression and not so much to the external referent.

\subsection{Floch and News cigarettes}

The tools of plastic semiotics and of the semi-symbolic were first applied to advertising by Jean-Marie Floch. His varied output includes an essay entitled "Sémiotique plastique et communication publicitaire" (1985), in which he develops the concept of semi-symbolic semiotics, applying it to a print advertisement for News cigarettes that appeared in 1980. He convincingly demonstrates that the elements on the plane of expression and on the plane of content can be analyzed independently prior to moving on to an overall reading.

As far as the plane of expression is concerned, Floch subdivides the total surface of the advertisement into three horizontal bands: an upper band, containing a typographic block dominated by the heading ("News"); a lower band, which contains the words "20 filter cigarettes"; and a central band consisting of a series of irregular polygons and a central colored area. The relationship between these bands can be clearly explained by drawing on the topological category of plastic semiotics. The central puzzle band is "inserted" (intercalé) with respect to the other two, which are topologically "insertive" (intercalant). Concentrating on the central band, it emerges that, as a result of a mise en abime effect, the colored area (what is recognized at the figurative level as "packet of cigarettes") has a very similar topographical organization to that of the advertisement as a whole, even though there are a number of differences (for instance, the fact that the central band of the advert has a topologically 


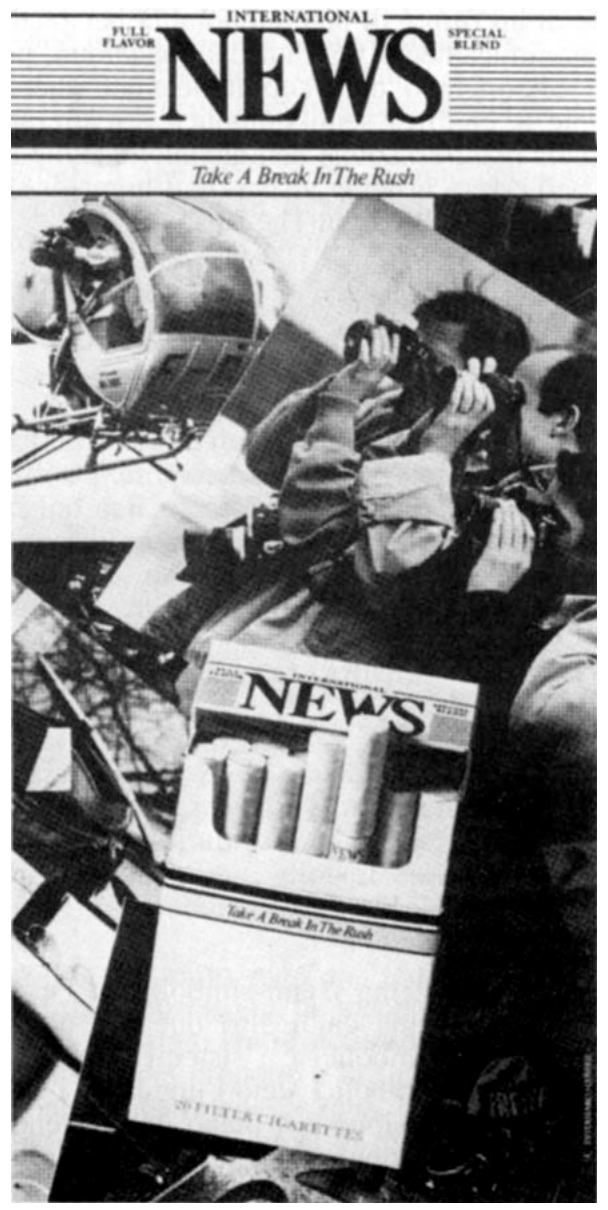

Figure 3. Advertisement for News cigarettes (1980)

irregular and polychromatic organization, while that of the cigarette packet is regular and monochromatic). All the graphic and chromatic oppositions that Floch succeeds in finding (for example, between parallelisms and irregular grids, symmetries and asymmetries, pure colors and shades, the polychromatic and the monochromatic) can be traced back to the same category on the plane of expression: continuity versus discontinuity. ${ }^{7}$ Floch then moves on to explore the content plane of the advert as a whole, which is presented, complete with title and masthead, as the "front page" of a daily newspaper. So what exactly does the notion of /front page/ refer to? It is where the day's most important news items, the most illuminating or exciting stories, are presented. It also 
emerges clearly on the front page that journalistic discourse is a distinct (and at times collective) creation, starting with the discourse of others, which are world events. At the figurative level this journalistic work is presented inside the central band, where there is a series of photos depicting various moments in a reporter's life, with the reporter busy working on a reportage or having a break, during which the tools of the trade are placed on the bonnet of a Land Rover and on the ground. However, these photographs are scattered around and overlapping, waiting to be selected and ordered by the editorial team. Viewed together, they clearly show the phase of the creation of the front page of a newspaper, a phase in which it is necessary to attribute a new meaning, starting with products that already have their own unit of meaning. This is exactly what editing is all about: "to create" something by exploiting input from the outside world (see 1985: 154).

It still has to be established what the half-open packet of cigarettes lying on top of the photos means, especially in relation to the words. Besides the brand name, News, and words describing the special qualities of the product ("full flavor," "special blend," "20 filter cigarettes"), there is also the claim: "Take a Break in the Rush." This contains the interpretative key to the entire advert. In fact, it is now clear that the packet of cigarettes metonymically represents the work of the journalist, who can take a break by smoking the advertised product. In addition to this, there is also a correspondence between the creation of the newspaper and that of the cigarettes. "Just as the newspaper is a personal creation resulting from the selection and arrangement of news items, likewise a News cigarette is the creation of a particular aroma resulting from a special blend of tobaccos" (Floch 1985: 156, my translation).

At this point in his analysis Floch introduces a category capable of explaining the entire content of the advert: /identity/ versus /otherness/. The identity of news and cigarettes stems from the raw materials elaborated by others (the reportage photos become news and tobacco becomes a cigarette). The advert also contains a "perfect" semi-symbolism, because there is an exact match between a category from the plane of expression and a category on the plane of content: corresponding to otherness is expressive continuity (that is, the work of the reporters expressed through irregular polygons, single colors), while corresponding to identity is discontinuity (journalistic work expressed through regularity, graphic parallelisms, chromatism in intervals).

\section{Audiovisual advertising: From narrative to passion}

\subsection{Greimas's "generative trajectory of meaning"}

While visual semiotics seems to be a particularly useful tool for understanding the organization of print advertisements, the "generative trajectory of mean- 


\begin{tabular}{|l|l|}
\hline Discursive structures & $\begin{array}{l}\text { Figurative isotopies (space, time, actors) } \\
\text { Thematic isotopies }\end{array}$ \\
\hline \multirow{3}{*}{$\begin{array}{l}\text { Semio-narrative } \\
\text { structures }\end{array}$} & $\begin{array}{l}\text { Canonical narrative schema } \\
\text { Actantial syntax (subject/object, sender/receiver, } \\
\text { helper/opponent, narrative programme) } \\
\text { Modal structures (wanting-to-do, } \\
\text { knowing-how-to-do, having-to-do, } \\
\text { being-able-to-do) }\end{array}$ \\
\cline { 2 - 2 } & $\begin{array}{l}\text { semantics and elementary syntax } \\
\text { (semiotic square) }\end{array}$ \\
\hline
\end{tabular}

Figure 4. Generative trajectory: discursive structures and semio-narrative structures.

ing," also developed by Greimas, is more appropriate for analyzing audiovisual advertising. As I argued in a recent book on this subject (see Bianchi 2005), analyzing an advertising spot requires a gradual, step-by-step procedure. First, it is necessary to divide the text into segments, effecting a shot-byshot or sequence-by-sequence découpage of the kind traditionally used in film analysis (see Mast and Cohen 1985). Only after this first stage of analysis it is possible to begin considering the complexity of the spot, dealing with the socalled immanent levels of the text, that is, the discursive and semio-narrative structures. These structures are two hierarchically ordered phases of the socalled generative trajectory, a model of analysis that proceeds from the manifested surface of the text to its deeper organizational forms, from the particular to the general, from concrete to abstract, as shown in figure $4 .{ }^{8}$

The generative trajectory therefore concerns the discursive structures where the major oppositions running through the text are established and its homogeneity (isotopies) ensured; where the narrative functions are filled by one or more characters; and where the enunciation has a more abstract and figurative nature. In order for a text to come into being, there needs to be an act of enunciation that defines a spatio-temporal structure and a structure of actors, standardized scenes that may be more abstract (themes) or more concrete (figures of the world). Essentially, Greimas's idea is that there is a subject of the enunciation that, in the act of creating a text, projects out from the contingent "I-here-now" of the creative act phenomena other than self and with other spatio-temporal coordinates. Semiotics must conceive this projection as a "detachment" (débrayage) from this act, as the only possibility that exists to 
identify simulacra of presence, given that the "real" author of the text never appears in the discourse.

However, the most complex part of the generative trajectory are the semionarrative structures. These consist of the syntactic and semantic virtualities of the system, of what at the surface level gives rise to the actantial structures, modal structures, and the canonical narrative schema, and, at a deeper level, to the semiotic square. The latter is, in fact, the elementary structure, and is more abstract and profound, i.e., the root opposition that enables meaning to be grasped. ${ }^{9}$ At a superficial level of the semio-narrative structures are the relations of the square converted into utterances of state and of doing, together with possible combinations thereof. This is the site of anthropomorphic narrativity, where the logical-syntactic relations of the terms in the square are transformed into the actions and wishes of subjects which, as they have no empirical status, exist only as a function of each other (which is why they are called actants $)^{10}$ and interact according to a narrative trajectory that Greimas considers to be canonical. The canonical narrative schema, as Greimas calls it, is an abstract framework that can be used to analyze any text and to identify variations and narrative recurrences. According to Greimas, every narrative has, a priori, a goal, a task to perform, an object of value to attain. This stage corresponds to the Performance, that is, to the central phase of the narrative in which the subject performs a given task and successfully completes the Narrative Programme by coming into possession of the valued object. The performance phase is preceded by two other moments: the contractual moment of the Manipulation, in which the subject interacts with a manipulator-Sender who is a repository of values; and that of Competence, in which the subject acquires the material or conceptual means, in the form of modalities (wanting-to, having-to, being-able-to, knowing-how-to-do), required to carry out the task established with the Sender and which will be realized in the Performance phase. In many texts, however, the narration does not end with the action but only when that action has been recognized as having been performed by the Sender, who confers a Sanction (positive or negative) on it.

As the generative trajectory of meaning is a general organization of signification, it should be clear how it can be satisfactorily applied to an advertising spot, and it is also a good way for students to "try out" semiotic theory. It can undoubtedly be adopted, in my view, as a means of achieving a fuller understanding of an advertising spot (or any other text), but in some cases it seems to raise problems rather than solve them. Moreover, in other instances it seems unable to account for certain dimensions of meaning that emerge from the analyzed texts. A narrative analysis of an advertising text is capable of explaining the pragmatic dimension, that is, the actions of the agent subjects, but completely ignores the pathemic dimension, and therefore the modulation of the states of mind of the subjects in the narrative. The latter has assumed increas- 
ing importance in semiotic studies in recent years, given that an analysis of any text reveals that every action has some form of pathemic involvement on the part of the subject of the doing and that actions and passions therefore run along parallel to each other or at any rate are closely interrelated.

\subsection{The semiotics of passion}

In the mid-1980s, some semioticians began investigating the emotional sphere of the subjects involved in narrative actions. The first study was De l'imperfection (1987), in which Greimas considers the emotional and sensory component of daily experience, succeeding, after a fashion, in closing the gap between the subject and the world. Through aesthesia, namely the ability to perceive or feel sensations, the subject is able to move beyond the ambit of "seeming" and to enter in a transitory way in the realm of "being" and of truth, insofar as this is a sensorial conjunction with the world.

A fundamental contribution to this area of study was Sémiotique des passions. Des états de choses aux états d'âme, written by Greimas and Jacques Fontanille in $1991 .{ }^{11}$ In this work, a new dimension was introduced to the semiotics of action. The semio-narrative and discursive models were reworked to take account of the emotional universe, which had been present, but with little emphasis, in the generative trajectory of meaning. All the different levels of semiotic analysis were now involved. From a more abstract, deep-semantic point of view, attention was given to the thymic category expressed by the euphoria/disphoria opposition, an overdetermination of the other categories present in the text at a more superficial level. ${ }^{12}$ From a narrative point of view, it was noted that manipulation, the initial phase of the canonical narrative schema (see 4.1.), is not possible without some emotional involvement on the part of the subject. ${ }^{13}$ Finally, from a discursive point of view, passions emerge as "effects of meaning," configurations and pathemic roles associated with thematic roles. ${ }^{14}$

\subsection{Advertising passion}

But how is modern advertising analyzed by the semiotics of passions? Not much work has in fact been done on the paths of passion in advertising texts, ${ }^{15}$ although the issues of aesthesia and synaesthesia (including that of advertising), first dealt with by Greimas in De l'imperfection (1987), continue to attract attention. Treating aesthesia as a new link between the subject and object of the aesthetic experience, Greimas considered the levels of depth of sensory experience; in his view, all five senses deserve to be studied, not only the senses associated with cognitive activity (sight and hearing) but also those that tend to 
be relegated to a secondary position (touch, smell, taste), which, in actual fact, are unquestionably "deeper" in that they constitute an intimate relationship between subject and object. In aesthetic experiences, there is a redefinition of the senses: the gaze becomes tactile, gustatory (as happens in many food ads) or odoriferous (prevalently in perfume ads).

Sensory experience thus becomes a horizon of resemanticization that, according to Bertrand (1995: 24-26), is the modern replacement of the great political ideologies with an ideology of the sensory in all its various forms. Indeed, contemporary reality has led to a weakening of our sensorial bonds with things, an "anaesthesia of the immaterial" that is accompanied by a corresponding enhancement of aesthesia, of sensory experience as such. Individual experience therefore extends to collective social conventions, with aesthesia being granted the status of social discourse, a kind of "prepackaged feeling." As Bertrand argues, "we only become impassioned within already-said and formed passions" (1995: 30, my translation); this is evident in women's magazines, in fashion, and in the advertising world in general, where the sensory aspects of experience are played up by means of images that underpin synaesthetic modalizations.

In classical rhetoric, synaesthesia is a form of metaphor that associates terms belonging to different sensorial systems, as, for example, in expressions like "smooth wine," "hard sound," and "sweet music." When referring to syncretic texts like those of advertising, the most common forms of synaesthesia are visual-auditory or visual-tactile, depending on the type of substance of the expression employed. In any case, the aim is to activate a multisensorial process (in marketing this may take the form of the aromatization of sales areas and the use of specially devised soundtracks), a multisensoriality that may also be "mediated" by synaesthetic representations (various advertising or promotional formats). In the case of the latter, one or more of the senses (visual or visual-auditory) are activated so as to induce a sensation that is not physically produced by the perception of its substance, as happens, for instance, in advertisements for perfume, which is a "difficult" product to advertise because it is all about a sense, that of smell, that can only be activated metaphorically (see Ceriani 1994).

In order to gain a better understanding of this area of passion-related semiotics, it is important to bear in mind the peculiarities of persuasive discourse in general (including advertising), of its manipulative action-inducing procedures, which, as Paolo Fabbri has said, are profoundly associated with the passions.

The issue of passions also arises when one realizes that the planning and execution of a strategy of manipulation, of an attempt to get someone to do something, does not automatically entail its success ... No action-inducing tactic is automatically successful; 
there is an intermediate stage to causative actions, a getting-someone-to-be that concerns the very being of the person on the receiving end of the action (the patient), and which contains an unknown element, namely the perspective of the recipient, his or her passion. (Fabbri and Sbisà 2001: 238, my translation)

Relating this to the analysis in hand, one might say that the persuasive action of advertising - "getting someone to do something" — will only be effective if an intermediate "getting someone to be" also takes place. And it is by no means incompatible with the above to point out that in actual fact advertising communication is first and foremost a "getting someone to want," because it activates modes of thought, value systems, and categories that shape consumer habits (see Ferraro 1999: 82-84). In short, the modern nature of advertising can more readily be grasped by viewing it as more closely linked to passion than to action, because it is a "form of impassioned communication" (Melchiorri 2002: 112).

Some of the characteristics of passion as it is enunciated in advertising discourse can be identified. First, there is a prevalence in modern advertising of euphoric investment, which invites intense involvement on the part of the subjects concerned at the expense of the "argumentative-informative" strategy. Second, there is a preponderance of passions relating to the present (envy of someone else's snack, smooth skin or cleaner jersey) or the future (especially in ads about social issues), while those relating to the past are rather more problematic. $^{16}$

It should also be borne in mind that advertising passion may take the form of enunciated passion, when the inception, transforming, and manifesting of a given emotion of passion is staged, or it may be an impassioned discourse, when the passion is not the content but the form of an enunciation, in that it is a projection of simulacra. In this research a fundamental role is played by one of the phases of the canonical passional schema (see 3.2., note 13), that of emotion, in which the passion emerges from the subject and is displayed, in a simulacral fashion, in the body, which becomes a vehicle of meaning and communication. Analyzing impassioned enunciations in ads means seeking out the simulacra of the presence of emotion that might reveal themselves in written or spoken language, in film language and even in musical language. This is a very complex and challenging form of analysis, but is undoubtedly very fruitful when it comes to studying modern advertising and marketing texts.

\section{Semiotics and marketing}

Thus far, the prevalent focus of this study has been textual (narrative and passional), which has rather pushed into the background the fact that advertising 
is also a form of communication that interacts with other forms within a specific cultural and social context. In fact, in contemporary society, advertising seems to be establishing itself increasingly not just as an independent language but also as a distinct form of discourse, a "configuration that acquires, in a given moment and in a given society, a specific set of social practices, patterns of interest, social groups, ethical convictions and cultural orientations" (Semprini 2003: 101, my translation). Once it occupied an interstitial and marginal role in social dynamics, but now it has developed its own discourse, with its own way of representing social actors and the interaction between them, providing models for social discourse itself; "advertising thus became a common cultural form, a generic social discourse, a producer and reproducer of a vision of social reality based on the values inherent to the two paradigms - economics and communication - from which it draws its energies" (Semprini 2003: 105 , my translation).

The growing theoretical awareness of the general role of advertising in modern society started with observation of the way in which the products in a given advertisement are valorized so as to become desirable for potential consumers. As it is not pertinent to their discipline, semiotic and socio-semiotic studies ${ }^{17}$ have not, however, investigated the productive strategies involved or the way in which individuals perceive and desire the publicized product. Instead, they have concentrated on what might be defined as the forms of the collective imagination of consumption. However, as Ferraro (1999: 95-106) stresses, it is not easy to get at those structures of collective thought, and research techniques have always aspired to "translate the individual into the collective," empirically observed data into structures of thought. Without moving beyond the ambit of desk-based textual research, ${ }^{18}$ it can be noted that references to cultural elements or collective myths can be identified in spots or print advertisements, to the extent that the individual analyzed text is "a kind of ongoing, spontaneous and very rich group discussion in which everything is defined, commented on and reformulated into new texts" (Ferraro 1999: 100, my translation). For this reason, it is necessary, even when studying the valorizations of a specific text, to consider it as an individual element in an "intertextual chain" and to compare it with other texts within the same social scene. Some of Floch's studies on the system of consumer values have been of vital importance in this respect.

\subsection{The search for values}

In 1990, Floch published his Sémiotique, marketing et communication, a fundamental work for understanding how semiotic theory and advertising communication can interact. In it, he presents some instances of market research 
that use and "test," as he reiterates on various occasions, semiotic theory itself. This mix of theory and practice forms the basis of many of Floch's works; on the one hand, he is particularly concerned to show advertisers the real utility of semiotic categories and, on the other hand, to point out to semioticians the theoretical pertinence of a world widely regarded as rather insignificant. The result is reciprocally enriching (see Floch 2001: ch. 2).

By analyzing publicity, the semiologist can extend the range of texts for study, while the marketing and advertising researcher may derive a three-fold benefit from semiotic theory:

1. greater intelligibility - the discovery that the "nebulae of meaning" on which many advertising campaigns are based conceal concepts that can be semantically defined in a much more precise way;

2. greater pertinence - semiotics makes it possible to distinguish and create a hierarchy of expressive elements according to homogeneous levels of description, identifying semantic variables and invariants that are produced in the various stages of the "generative trajectory of meaning" (see 4.1.);

3. greater differentiation - the identified elements no longer need to be considered in isolation but can be related to each other in accordance with the rules of interdefinition of the semiotic square: contrariety, contradictio,n and implication (see 4.1.).

In particular, by exploiting the potential of the semiotic square to the fullest, Floch manages to construct a typology of forms that advertising communication draws upon in order to valorize the objects that need publicizing; the result is the celebrated square of consumer values (see Figure 5), which is still the most well-known and widely used semiotic tool in marketing and advertising communication.

Analyzing an extensive sample of car advertisements, Floch identifies four ways in which the Object is valorized by the Subject: practical, playful, criti$\mathrm{cal}$, and utopian. Practical valorization may be effected in a print advertisement if the Object is considered as an instrument, with the emphasis on easeof-handling or level of comfort. On the other hand, there is playful valorization if the Object is considered in terms of its formal and physical qualities, the pleasure it gives and its general beauty; in this case, value is attributed to the car not insofar as it is a means of transport but simply for the pleasure of possessing or driving it. In contrast to playful but complementary to practical valorization, there may be critical valorization, where the economical nature of the Object is stressed, as happens in ads for cars with low fuel consumption. Finally, there is a utopian valorization, which is contrary to the practical and complementary to the playful; in this case, the advertising story does not focus 


\section{FLOCH'S SQUARE}

Practical Valorization

(e.g., ease-of-use,

comfort, reliability)

"Utilitarian" values

(use)
Utopian Valorization

(e.g., quality of life,

identity, adventure)

"Existential values"

(basic)

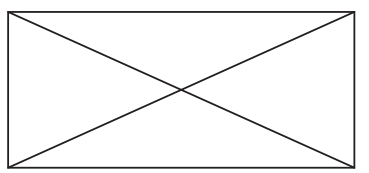

"Non-existential" values

(e.g., cost, quality/price

ratio, advantages)

Critical Valorization
"Non-utilitarian" values

(e.g., gratuitousness, sophistication, fun) Playful Valorization

Figure 5. Square of consumer values (after Floch 2001)

on the object as such but on the Subject, who will achieve deep inner fulfillment through union with his or her Object of Value. This happens, for instance, when there is total identification between the driver's personality and the car itself. The four types of valorization are intended to correspond to the possible "forms of rationality" adopted more or less consciously by consumers when purchasing a product (see Marrone 2001: 175). These include a calculation of the economic advantage or the utility of the product, though they are not the only criteria according to which consumers are called upon to make their choice. Indeed, the more immaterial and evanescent values seem to be of increasing importance.

Floch's square drew a considerable amount of attention from semiologists, who discussed and developed it at length, sometimes modifying it substantially. ${ }^{19}$ In attempting to adapt semiotic tools to suit the requirements of marketing, these works have often ended up emphasizing the classificatory nature of the square, with the result that individual texts were empirically tied in with the pre-established typology (this ad is based on these types of values, the company exploits these discursive strategies to stand out from the competition, etc.). But in doing so, there was a tendency to forget what Floch himself had repeatedly emphasized, namely, that the good health of a square is measured by the path that can be taken with it (see Floch 1990). This implies that the square of axiologies should not be understood just as a "static schema illustrating a series of possible alternatives, but as a practical tool useful in piecing 
together the inner workings of texts, the semantic transformations that are present in the various advertising stories" (Marrone 2001: 182, my translation). Market research and marketing can benefit greatly from the possibility of investigating such values. These may relate to or contrast with those of other brands (analyzed synchronically), or may be contiguous with previous ones (analyzed diachronically), but which together make up the identity of the brand itself.

\subsection{The brand: Between possible worlds and enunciation}

In addition to the study of axiologies, another fundamental aspect of marketing investigated by semiotic analysis is the discourse of the brand. Indeed, the now classic analysis of brand function by Kapferer and Thoening (1991) lies on the boundary between marketing and semiotic studies. Product identification, orienting of the offer, guarantee, customization, playfulness, and practicality are all functions performed by the brand on behalf of the consumer. Acting as an intermediary between product/company and consumer, the discourse proposed by each brand should be traceable as a whole in all the elements traditionally studied by marketing: advertising, packaging, logo, products, sales channels, pricing policy. All these elements have become areas of study for semiotics, both those that are traditionally more receptive to textual analysis, such as the various textual forms of advertising (print advertisement, posters, and spots) and the others, which in recent years have been dealt with prevalently by sociosemiotics, which is highly attentive to phenomena traditionally treated by sociology, for example, media reception and modes of consumption.

The brand/semiotics pairing is all the more justified when one considers the fact that brands act as signs, and therefore as fundamental semiotic devices. Above all else a brand is a mark, an attribution of a name to an otherwise anonymous product lacking established qualities (see Volli 2003). Brands are also metasemiotic in nature, positioned as they are above individual products. The brand therefore has a dual nature: on the one hand, it is a synthesis of the values of the products in the same range, on the other it creates for the latter a broader discursive context, a kind of background scenario that can also prove decisive for the attribution of meaning to an individual product (see Ferraro 2000). Also deriving from this is a two-fold communicative position: it is the object of discourse, when in advertising communication it is constructed, qualified, and integrated more or less organically with the object, becoming a significant component of its identity and value; on the other hand, the brand is a customized and active reality, a subject that organizes and conducts a discourse (see Semprini 1993). 
Ferraro (2000) emphasizes that it is possible to focus on one or other of these perspectives as a strategic choice. But an objectivizing analytic perspective, which is more attentive to the affirmation of industrial values as such and their declination in various forms of communication, has gradually been abandoned in favor of a more subjectivizing perspective. Communication now seems to focus prevalently on the brand as a subject that produces its own discourse, which tends to lay emphasis on the values of /personality/, /exclusiveness/, /innovativeness/, and above all /authoritativeness/, and to facilitate the creation of a specific brand perspective. Semiotics plays an important role in all this.

As Semprini and Musso (2000) emphasize, if semiotics abandons its longheld role as a critical tool for all the various textual forms, it can account for the essence of the brand, its meaning, and symbolic nature. A brand can aptly be defined as "a semiotic phenomenon, a way of segmenting and attributing meaning in an orderly, structured and voluntary fashion" (Semprini 1996: 55, my translation). It is therefore a complex system of signification organized into a generative trajectory of meaning (see 4.1.): at the level of semio-narrative structures it embodies values or objects desirable for a subject; such values are taken on board by actors of the narration in the ambit of scripts that are standardized in terms of their discourse structures. While the values remain the fundamental nucleus of the discourse that enables the brand to act as a mediator between the worlds of production and consumption and must therefore remain constant, at the level of the enunciation there is great variability in expressive means (print advertisements, spots, promotional events and so on).

A brand tells us various kinds of stories, thereby constructing possible worlds ${ }^{20}$ in order to give substance and content to its basic concepts. Like a literary text or any other creative work, the brand constructs possible worlds that are furnished in a specific way and characterized by a list of its own specifications (Eco 1979, 1990). In building such fictional universes, it is possible to depart to a greater or lesser degree from the world of our concrete experience, ${ }^{21}$ and it is the presence of the brand that helps to distinguish the real world from the possible one. The latter must satisfy the requirement of internal coherence, which stems from cooperation between the brand and its receivers. In fact, by subscribing to the imaginary construction offered by the brand, consumers attribute a real existence to the fictional universe in the imagination of consumption, and strengthen the identity of the brand itself. Without wishing to downplay the value of these studies on brands, other semiotic tools might also be useful in understanding the dynamics between the various discourses present in advertising messages, in the circulation of objects of consumption and in brand communication. In particular, reference might be made to the theory of enunciation, a powerful theoretical tool whose potential could fruitfully be exploited. 
Semiotic theory basically upholds the principle that every type of text (written, visual, audiovisual) has an autonomy and independence with respect to the circumstances prompting its creation, and also with regard to the hypothetical reader, who may interpret and receive it in different ways. As is known (see 4.1.), there is a process of "disengagement" (débrayage) that "detaches" the text from the empirical addresser and empirical addressee alike. But what is particularly interesting is that it is possible to detect traces of the addresser and addressee (traces produced by a process of embrayage) in the texts themselves. Such traces constitute simulacra of the enunciation, in a similar way, with respect to the addresser, as the use of the first person "I" in narrative texts. Other examples include the use of self-portrait in the figurative arts, or signatures, or - and this is what is of specific interest - the brand on a product (or the relative publicity). On the other hand, the addressee may also be represented in various ways: the use of "you" and the buttonholing of readers in narrative texts, or the framing of visual texts by the camera, a powerful semiotic circuit of the gaze. These semiotic devices, and various combinations thereof, are used regularly to articulate advertising communication, and the brand, in its role as addresser present in the text, must find its own specific position though this will not necessarily be identical in every textual occurrence. It can be noted, for example, that the textual strategies used by a brand to engage the addressee might change over time, though every effort will be made to present a basic coherence of discourse as a brand.

Besides rendering itself explicit on the level of enunciatory strategies (brand as the pragmatic subject of a possible world), the presence of the brand can (and must) render itself explicit within the enunciation by means of an enunciatory embrayage such as the introduction of the logo or the designer label on a product or item of clothing. From a semiotic point of view, then, the brand is an example of "delegated enunciation" as expressed in schematic form in Volli (2003: 69-70, 89-94).

The empirical sender is the corporation that actually makes and puts the product into circulation, projecting into the object and the relative communication a "delegated sender," which coincides with the brand, to which it attributes

\begin{tabular}{|c|c|c|c|}
\hline $\begin{array}{l}\text { Empirical } \\
\text { sender } \\
\rightarrow \text { (business) }\end{array}$ & $\begin{array}{l}\text { Delegated } \\
\text { sender } \rightarrow \text { object } \rightarrow \\
\text { (brand as } \\
\text { addresser) }\end{array}$ & $\begin{array}{l}\text { Delegated } \\
\text { receiver } \\
\text { (target as } \\
\text { addressee) }\end{array}$ & $\begin{array}{l}\text { Empirical receiver } \\
\rightarrow \quad \text { (consumer) }\end{array}$ \\
\hline
\end{tabular}

Figure 6. Diagram on the "delegated enunciation" 
certain specific characteristics. In the case of particular forms of communication, such as institutional advertising, the delegated sender coincides with what is known in advertising as the corporate image or corporate brand (see Volli 2003: 94-96). A similar delegation can also be found on the right-hand side of the schema. Besides the construction of a brand as the "delegated sender" there is a corresponding delegated receiver identified as the target, which may coincide to a greater or lesser extent with the empirical receiver, i.e., the consumer, who purchases the product.

The various elements of the brand, the publicity, the packaging, logo, choice of products, sales channels and communication, pricing, and all the communicative means devised by marketing should in theory contribute actively to creating coherence in the brand discourse, even though this is manifested in concrete terms in a heterogeneous range of communicative products and expressive media. It should also be added that in advertising the representation of the enunciator is highly redundant: the trademark, logo, packshot, and all the other signs codified as correlatives of the brand; for instance, jingles (Volli 2003: 69), create an enunciatory redundancy designed to remain impressed in the spectator's memory. This redundancy is based on a highly cogent intertextual isotopy which is communicatively effective if it is found in all the various manifestations associated with the product and its publicity, and likewise with the sales outlets or the manufacturer.

\section{Conclusion}

By way of conclusion, it is worth making a general observation about semiotic perspectives, lying as they do between textuality and marketing. It is important to emphasize how a good description of the phenomenon of brand and of publicity must take adequate account of the superimposition of the two forms of communication, the objective communication and the metalinguistic and persuasive one, which consists of continually reaffirming the mere existence of the brand itself. While semiotic studies initially focused on the results of the communicative strategy of the brand (especially in the study of advertising messages and texts), and subsequently on the identity and personalization of the brand discourse as a pragmatic subject, it might now be fruitful to concentrate on the relational dynamics between what is enunciated and the enunciation, without prematurely subordinating the former to the latter. There is a need for greater caution in examining the dynamic between enunciated discourse and brand discourse, because the greatest problem that needs to be faced, especially in audiovisual communication, concerns syncretism and possible imbalances in the enunciation as a whole. In fact, with increasing frequency, it is 
possible to note a strong degree of incoherence or instances of "partial" coherence in brand communication: a poster put up in the wrong place, a spot transmitted in an inappropriate slot, a product sold at a supermarket where one would least expect to find it. The coherences within the brand (diachronic and synchronic coherence) also require contextual coherence, something that does not always receive adequate attention. This appears to be due to the overall pervasiveness of brand discourse (and above all of advertising communication), which does not necessarily imply specific choices on the part of the companies concerned. What often seems to prevail is the logic of merely establishing a "presence" in the crowded field of communications rather than positioning one's discourse in a clear-cut fashion, which of course involves sacrificing something and relying on the value and overall coherence of what one has to offer.

\section{Notes}

1. Classical rhetoric is divided into five parts: inventio (or euresis), which is the technique for building discourse topics; dispositio (or taxis), the arranging and rhythm of topics; elocutio (or lexis), the art of "embellishing" discourse with various figures and tropes; memoria (or mneme), a collection of mnemonic techniques for remembering speeches without the aid of a written text; and actio (or ypocrisis), the art of delivery, including use of the body and tone of voice. The most frequently treated areas in contemporary rhetoric are inventio and elocutio, while the last two, memoria and actio, are no longer considered an integral part of rhetoric (see Corbett 1999).

2. According to Barthes (1967), the sign as understood by Saussure, i.e., the pairing of a signifier and a signified, is able to communicate something more than just its primary meaning (denotation) by means of a connotative mechanism whereby the first sign becomes the signifier of a new signified. The code is a system of correspondences linking, according to socially accepted rules, a system of signifiers and a system of signifieds.

3. Before going any further it is worth remembering that although these reflections on the advertising message may seem somewhat ingenuous to us today, they must be read from a historical perspective and therefore in relation to the type of advertising employed in the 1960 s, which was undoubtedly much more informative and "direct" than what we are used to seeing nowadays.

4. Barthes's idea that photographs are "messages without a code" prompted heated debate about whether or not visual codes are conventional. Over the years the academic world divided into two camps: those who took the line that the mechanisms of perception are universal and those who held that they were cultural and conventional in nature. For an in-depth discussion of the so-called iconicity dispute, see Fabbrichesi Leo (1983).

5. This was also pointed out by Marrone (2003: 294), who observed that some sociological studies consider the work of Barthes and Eco to represent the current horizons of advertising semiotics.

6. When Greimas investigates the relationship between the plane of expression and the plane of content, he makes reference to the theory of Louis Hjelmslev, who was the first to talk about two planes of language (expression and content) that are interdependent in the sign function (see Hjelmslev 1961). 
7. Irregular polygons, single and soft colors can be related to the category of continuity, and parallel lines, polychromatism and pure colors to discontinuity.

8. In particular, see Greimas (1970, 1983), Greimas and Courtés (1982), Bertrand (2000).

9. Starting with a fundamental semantic opposition, the semiotic square defines its terms with abstract syntactic operations of contradiction-contrareity and affirmation-negation (see Greimas and Courtés 1982).

10. The actants of the narration, insofar as they are abstract roles, are limited in number: Subject, Object, Sender, Receiver, Opponent, Helper. It is worth stressing that each actant may be filled by a varying number of actors; in other words, a single actor may occupy more than one actantial role, just as more than one actor may occupy a single actantial role (see Greimas 1983; Greimas and Courtés 1982).

11. The bibliography on the semiotics of passion is increasing, and now includes a number of highly sophisticated and complex studies. See, among other works, Fabbri and Sbisà (2001), Fabbri (1987, 1998) for a general consideration of the passional; Pezzini (1998) and Marsciani (1999) for studies of passions in literature; Marrone (1998) for news presentation in journalism; Marrone (2001) and Melchiorri (2002) for passion in advertising. Above all, the work of Jacques Fontanille, commencing with Sémiotique des passions (Greimas and Fontanille 1993), offers an in-depth study of the many aspects of the semiotics of passions.

12. Thymia is based on the movement of attraction and repulsion that regulates the euphoric or dysphoric orientation of the subject with respect to his/her objects. This can be illustrated by observing that there are euphoric passions (/joy/, /hope/) and dysphoric passions (/shame/, /fear/), but also passions that are neither euphoric nor dysphoric (/indifference/, /abulia/), and ones whose orientation changes according to the situation or a given moment (/love/) (see Fabbri and Marrone 2001: 222-224).

13. It was therefore hypothesized that the canonical narrative schema could be accompanied by a canonical trajectory of passion, that is, the canonical passional schema. The first phase consists of the establishment or "affective awakening" of the passion, while in the second, that of sensitization, this vague feeling begins to take shape through moments of disposition, pathemization, and, above all, emotion, when the somatic reactions (tremors, jumps and starts, agitation, quivering, etc.) are manifested, revealing whether the passion is expected or unexpected, bearable or otherwise. Then there is the final moralization phase of the schema, in which an intersubjective evaluation is made of the trajectory taken by the subject (see Greimas and Fontanille 1993).

14. While the thematic role concerns the doing of the subject, the pathemic role relates to the subject's being or state. This is a modal organization that transposes deep thymic investment onto a more superficial plane and is manifested through configurations described as pathemes, semantic units of the passional field (see Greimas and Courtés 1982).

15. In particular, see Bianchi (2005), Marrone (2001), and Melchiorri (2002).

16. Nostalgia only appears in advertising as a prelude to another, euphoric passion. Examples of this are Gavino Sanna's advertising campaigns for Barilla, in which the initial nostalgia of a subject who is a long way away from a loved one is resolved at the end of the spot with the longed-for reunion (through a long journey or via a computer screen); see Melchiorri (2002: 118).

17. It is not easy to come up with a definition of socio-semiotics because it tends to construct a system of significations that, while continuing to use semiotic tools, accounts for concrete social systems, such as consumer habits, information flow or new political dynamics. It seems reasonable to affirm, as Landowski puts it, that the purpose of socio-semiotics is to reconstruct the ways in which the social community puts itself on show and in so doing comes up with the necessary rules for its game (see Landowski 1989). 
18. It is quite common to distinguish between field methodologies, which consist of conducting interviews, and desk methodologies, which involve studying texts and attempting to highlight their construction and possibilities of meaning. The former are part of a typical sociological approach, while the latter can more readily be pursued with semiotic tools. However, as many studies have shown in recent years, starting with Floch's analysis of the route taken by a sample of travelers on the Paris subway (Floch 2001: ch. 3), this definition is perhaps not entirely clear-cut, and above all it is no longer possible to relegate semiotic research to desk-bound investigations; for more on this, see Ferraro (1999: 96-101).

19. See, for example, the "semiotic mapping" developed by Semprini (1993) and Ferraro's "theory of discursive regimes" (1999).

20. Possible worlds are universes of discourse that may or may not coincide with the propositional attitudes of the reader, depending on whether that person's encyclopaedia accepts the facts as reasonable and possible. A possible world is therefore a cultural construct, a structure of data pieced together by the reader on the basis of clues present in the text itself (see Eco 1979, 1990).

21. Eco argues that a narrative text may contain four different types of possible worlds (PW) depending on the compatibility of what is being narrated with the world of our concrete experience: 1) verisimilar worlds, when the worlds in question can be conceived without having to alter any of the general laws of physics that apply in our world of reference; 2) nonverisimilar worlds, when worlds are presented that cannot be pieced together on the basis of our current experience; 3) inconceivable worlds, when there are worlds that go beyond our powers of imagination because they contradict certain fundamental epistemological laws, above all the law of internal coherence (of non-contradictoriness); 4) impossible possible worlds, when the reader can take in enough to realize that the worlds in question are impossible (see Eco 1990: 75-79).

\section{References}

Barthes, Roland. 1967. Elements of semiology. London: Cape.

Barthes, Roland. 1972. Mythologies. London: Cape.

Barthes, Roland. 1977. Rhetoric of the image. In Image - music - text, 32-51. London: Fontana.

Bertrand, Denis. 1995. L'ideologia del sensibile. In Maria Pia Pozzato (ed.), Estetica e vita quotidiana, 23-34. Milan: Lupetti.

Bertrand, Denis. 2000. Précis de sémiotique littéraire. Paris: Nathan.

Bianchi, Cinzia. 2005. Spot. Analisi semiotica dell'audiovisivo pubblicitario. Rome: Carocci.

Ceriani, Giulia. 1994. Dal sincretico al sinestesico: le metafore del sensibile. In Roberto Grandi (ed.), Semiotica al marketing: Le tendenze della ricerca nel marketing, nel consumo, nella pubblicità, 120-132. Milan: FrancoAngeli.

Corbett, Edward P. J. 1999. Classical rhetoric for the modern student, 4th edn. New York: Oxford University Press.

Eco, Umberto. 1968. La struttura assente: Introduzione alla ricerca semiologica. Milan: Bompiani.

Eco, Umberto. 1979. Lector in fabula: La cooperazione interpretativa nei testi narrativi. Milan: Bompiani.

Eco, Umberto. 1990. The limits of interpretation. Bloomington: Indiana University Press.

Fabbri, Paolo. 1987. A passion veduta: Il vaglio semiotico. Versus 47-48. 203-233.

Fabbri, Paolo. 1998. La svolta semiotica. Bari: Laterza. 


\section{0}

\section{Bianchi}

Fabbri, Paolo \& Gianfranco Marrone (eds.). 2001. Semiotica in nuce: Volume II. Teoria del discorso. Rome: Meltemi.

Fabbri, Paolo \& Marina Sbisà (2001). Appunti per una semiotica delle passioni. In P. Fabbri \& G. Marrone (eds.), Semiotica in nuce: Volume II. Teoria del discorso, 237-249. Rome: Meltemi.

Fabbrichesi Leo, Rossella. 1983. La polemica sull'iconismo. Naples: Edizioni Scientifiche Italiane.

Ferraro, Guido. 1999. La pubblicità nell'era di Internet. Rome: Meltemi.

Ferraro, Guido. 2000. Entrare nel www. In M. Lombardi (ed.), Il dolce tuono: Marca e pubblicità nel terzo millennio, 169-189. Milan: FrancoAngeli.

Floch, Jean-Marie. 1985. Sémiotique plastique et communication publicitaire. In Petites mythologies de l'oeil et de l'esprit. Pour une sémiotique plastique, 140-186. Paris \& Amsterdam: Hadès-Benjamins.

Floch, Jean-Marie. 1990. Semiotics, marketing, and communication: Beneath the signs, the strategies. Hampshire: Palgrave.

Greimas, Algirdas Julien. 1970. Du sens. Paris: Seuil.

Greimas, Algirdas Julien. 1983. Du sens II. Paris: Seuil.

Greimas, Algirdas Julien. 1984. Sémiotique figurative et sémiotique plastique (Actes sémiotique 60). Limoges: Presses universitaires de Limoges.

Greimas, Algirdas Julien. 1987. De l'imperfection. Périgueux: Fanlac.

Greimas, Algirdas Julien \& Joseph Courtés. 1982. Semiotics and language: An analytical dictionary. Bloomington: Indiana University Press.

Greimas, Algirdas Julien \& Jacques Fontanille. 1993. Semiotics of passions: From states of affairs to states of feelings. Minneapolis: University of Minnesota Press.

Hjelmslev, Louis. 1961. Prolegomena to a theory of language. Madison: Wisconsin University Press.

Kapferer, Jean-Nöel \& Jean-Claude Thoening. 1991. La marca: Motore della competitività delle imprese e della crescita dell'economia. Milan: Guerini e associati.

Landowski, Eric. 1989. La société réfléchie: Essais de socio-sémiotique. Paris: Seuil.

Marrone, Gianfranco. 1998. Estetica del telegiornale: Identità di testata e stili comunicativi. Rome: Meltemi.

Marrone, Gianfranco. 2001. Corpi sociali: Processi comunicativi e semiotica del testo. Torino: Einaudi.

Marrone, Gianfranco. 2003. Panzani e Camay. Due testi esemplari nell'analisi della pubblicità. In Giovanni Manetti \& Paolo Bertetti (eds.), Semiotica: Testi esemplari. Storia, Teoria, Pratica, Proposte, 292-308. Torino: Testo \& Immagine.

Marsciani, Francesco. 1999. Esercizi di semiotica generativa: Dalle parole alle cose. Bologna: Esculapio.

Mast, Gerald \& Marshall Cohen (eds.). 1985. Film theory and criticism: Introductory readings. New York: Oxford University Press.

Melchiorri, Alessandro. 2002. La dimensione patemica negli spot. In Isabella Pezzini (ed.), Trailer, spot, clip, siti, banner: Le forme brevi della comunicazione audiovisiva, 111-145. Rome: Meltemi.

Pezzini, Isabella (ed.). 1998. Le passioni del lettore: Saggi di semiotica del testo. Milan: Bompiani.

Semprini, Andrea. 1990. Ed. Lo sguardo semiotico. Pubblicità, stampa, radio. Milan: FrancoAngeli.

Semprini, Andrea. 1993. Marche e mondi possibili. Milan: FrancoAngeli.

Semprini, Andrea. 1996. L'oggetto come processo e come azione. Bologna: Esculapio.

Semprini, Andrea. 2003. Lo sguardo sociosemiotico: Comunicazione, marche, media, pubblicità. Milan: FrancoAngeli. 
Semprini, Andrea \& Patrizia Musso. 2000. Dare un senso alla marca. M. Lombardi (ed.), Il dolce tuono: Marca e pubblicità nel terzo millennio, 43-66. Milan: FrancoAngeli.

Volli, Ugo. 2003. Semiotica della pubblicità. Bari: Laterza.

Cinzia Bianchi is an assistant professor at the University of Modena and Reggio Emilia <cinzia. bianchi@unimore.it>. Her research interests include mass communication, the semiotics of text, and the semiotics of advertising. Her publications include Su Ferruccio Rossi-Landi (1995); Spettri del potere: Ideologia, identità, traduzione negli studi culturali (2002); and Spot: Analisi semiotica dell'audiovisivo pubblicitario (2005). 